\title{
Distal transradial access in the anatomical snuff box for coronary angiography and interventions
}

\section{(DDelena Mikulan* \\ County Hospital Čakovec, Čakovec, Croatia}

RECEIVED:

February 19, 2020

ACCEPTED:

February 22, 2020

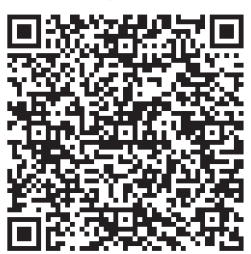

$\square$ Cardiologia Croatica 2020;15(3-4):66.
KEYWORDS: radial artery, anatomical snuff box, coronary catheterization, interventional cardiology CITATION: Cardiol Croat. 2020;15(3-4):66. | https://doi.org/10.15836/ccar2020.66

*ADDRESS FOR CORRESPONDENCE: Jelena Mikulan, Županijska bolnica Čakovec, I. G. Kovačića 1e, HR-40000 Čakovec, Croatia. / Phone: +385-99-7719-386 / E-mail: mikulanjelena@gmail.com

ORCID: Jelena Mikulan, https://orcid.org/0000-0001-6968-6483

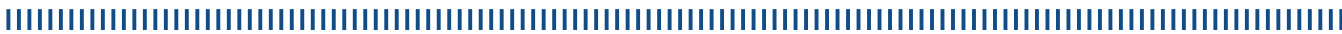

Radial access is today the most popular approach in coronary angiography. It decreases risk of bleeding and complications of peripheral vessels. New type of radial approach is distal radial approach in anatomical snuff box region. The aim of this paper is to provoke discussion in the field of interventional cardiology.

Distal radial artery access from the anatomical snuff box was described for the first time by Babunashvili in order to open occluded ipsilateral radial arteries in a retrograde fashion. It was then introduced for coronary catheterization as a new technique by Dr F Kiemeneij in April 2017 and in same year in December, Dr Shigeru Saito performed Kamakura live demonstration. The anatomical snuffbox is triangular deepening on the radial side of the wrist visible on extended thumb. ${ }^{1}$ Most operators prefer the right radial approach. The main reason is the working position of the operator on the right side of the patient. Distal transradial access on the left arm is the most convenient for the patient and the operator. For the right-handed patient, the left radial access is more convenient because of the free use of the right hand after the procedure. In addition, this technique reduces the chance of radial artery occlusion at the site of the distal forearm. Possible advantages of this approach are more physiologic (pronation) and painless arm position on the catheterization laboratory table, especially for the left arm, with an easier reach of the left arm. Preservation of radial arteries for arterial grafts (coronary artery bypass surgery, etc.), convenience for right-handed patients, easy wrist flexion after the procedure. Faster postprocedural recovery, shorter time for compression, easy manual compression and lower rates of artery stenosis, thrombosis and bleeding. There is a less chance for vascular compromise (danger only for the deep palmar arch, superficial is intact). Limitation is that the distal radial artery is smaller, making puncture more challenging, it has a long learning curve. ${ }^{2}$ Does the rise time follow for the distal radial approach?

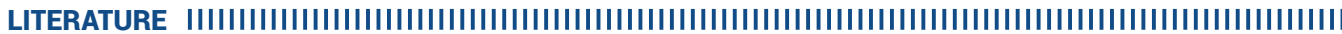

1. Gajurel R, Sahi R, Shrestha H, Thapa S, Khanal R. Initial Experience on Anatomical Snuff Box Approach for Coronary Angiogram \& Percutaneous Coronary Intervention in a Tertiary Care Center Nepal. World Journal of Cardiovascular Diseases. 2018;8;578-87. https://doi.org/10.4236/wicd.2018.812057

2. Kiemeneij F. Left distal transradial access in the anatomical snuffbox for coronary angiography (IdTRA) and interventions (IdTRI). Eurolntervention. 2017 Sep 20;13(7):851-857. https://doi.org/10.4244/EIJ-D-17-00079 